discussion with patients, relatives, or friends, but we couldn't fail to observe that in three homes, all Roman Catholic, patients and their relatives derived great spiritual help and comfort from the frequent visits of a priest.

\section{Conclusions}

In a limited way we have attempted to look at some of the social, medical, and nursing problems faced by women dying of pelvic cancer. From our base in a large teaching hospital we have looked outwards into the community we serve, but we are aware of our limitations and realize that others in closer and more continuous contact with patients in their homes could add much to what we have to say. We hope that they will be stimulated to do so.

On the whole our study leaves us with a sense of uneasiness. Compared with the costly and detailed investigation and treatments carried out initially in hospital we believe that too little attention is paid to the management of these patients in the terminal stages and to the peculiar difficulties they and their families face. Hardship for patients and their relatives could be eased if more beds of the right type were made available. We can see little point in patients with terminal cancer occupying beds in large, expensive hospitals ; quite apart from cost, we have known some of these patients to be intensely lonely in the middle of a busy acute ward. Beds for these cases are better sited in small local or cottage hospitals where family doctors can give the necessary supervision. We think it a pity that medical students do not have the chance to follow this type of patient out of hospital into the home so that they can observe, over a period, the harrowing preliminaries to death. There is so much for the student to learn about how to deal with patients and their relatives under stress, about the various agencies that can be called upon for help, and about the measures that can be taken to relieve pain and distress. These are matters of the greatest importance to all who practise medicine. But teaching hospitals have identified themselves with the management of acute illness rather than with the care of the chronically ill and the dying, and there is little opportunity for students to see or appreciate the sort of problem we have studied over the past three years. This failure is one of the important deficiencies of medical education to-day.

We were privileged to be allowed to observe these patients, and their relatives and friends, in their own homes during a period of great stress; their courage impressed us deeply. We are most grateful to the many family doctors and district nurses who gave us access to the homes and helped us in other ways. We should also like to thank the North of England Council of the British Empire Cancer Campaign for the generous grant which made the study possible.

\title{
Five Years' Experience With the Vacuum Extractor*
}

\author{
J. A. CHALMERS, $\dagger$ M.D., F.R.C.S., F.R.C.o.G.
}

Like so many " new" instruments the vacuum extractor has a long history of evolution. The Malmström instrument, now so widely used, represents merely a stage, albeit a highly efficient stage, in a story going back to 1704 (Yonge, 1706-7). The development of the method is still going on, and a number of newer instruments are becoming available. The Malmström instrument itself is undergoing modification. Evelbauer (1961), Rüther and Sokol (1961), and others have described electric pumps which they claim have made induction of the appropriate vacuum both easier and quicker.

At Worcester we have employed two different foot-pumps, the first derived from a Smith-Clark suction apparatus, and the second a stirrup attachment (see Fig.) devised by Malmström and Uddenberg and sent to us for trial. The object in both cases is, of course, to place induction of the vacuum under the control of the operator and to obviate the need of an assistant for this purpose. This may be an important advantage, particularly in domiciliary practice. In Rumania, Dragotescu and Roman (1962) have described their instrument, the "videx," which resembles the Malmström extractor in the form of the cup, but is fitted with a foot-pump and incorporates a vacuumrelease button in the traction handle. Chertkoff (1961), of Argentina, has also described a new instrument, the "ventosa extractora fetal " with a modified form of cup, which incorporates an electric motor operated by a foot-switch. It seems that we may look for further modifications and new instruments in

* Read to a ioint meeting of the Section of Obstetrics, Gynaecology, and Child Health and the Section of Physiology and Biochemistry at the Annual Meeting of the British Medical Association, Oxford, 1963. f From the Obstetric Unit, Ronkswood Hospital, Worcester. the future, but there is no doubt that it is the Malmström instrument which in the past seven years has shown obstetricians all over the world what a valuable contribution the

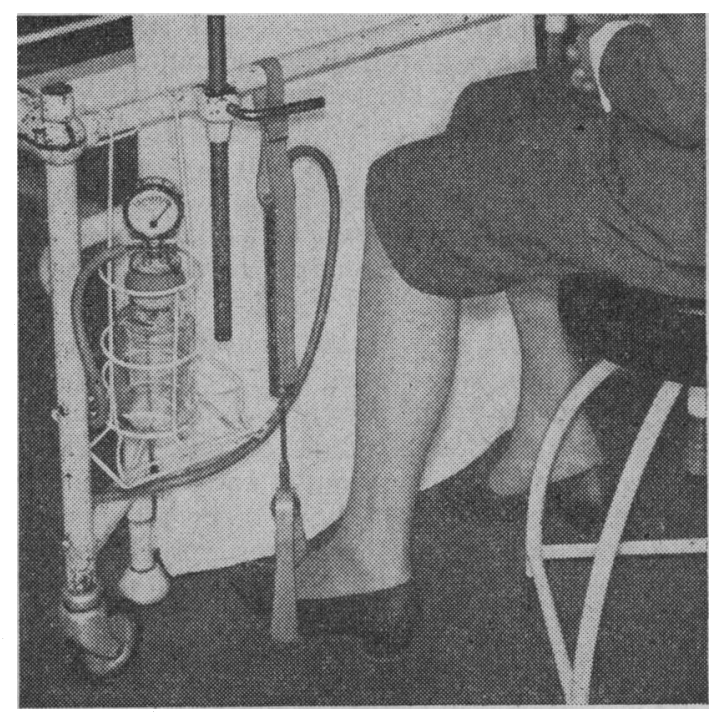

Stirrup-pump attachment for Malmström extractor.

vacuum extractor can make to many of the most difficult problems of obstetrics.

It was in the autumn of 1957 that Snoeck and Wilkin, in Brussels, first introduced me to the Malmström instrument, and 
their enthusiasm was such that we began to study its use at Ronkswood Hospital, Worcester, early in 1958. Since then we have employed it in 400 cases, and have come to value it more and more highly, so that to-day we regard it as indispensable in the management of many of our day-to-day problems. During these five years the instrument has been used by some 30 different operators, some of them house-surgeons new to operative obstetrics, and all have been quick to acquire skill in its handling. The results show what can be achieved by this somewhat miscellaneous group of operators ; the more difficult cases have, of course, been undertaken by more skilled and senior staff, and certain failures on the part of the junior staff might have been avoided by operators with greater experience. None the less, results show some improvement as our knowledge of the method has grown, and even in many cases of "failure" a valuable contribution to the safety of delivery has been afforded by the vacuum extractor, notably in completing dilatation of the cervix and in bringing the presenting part lower in the birth canal where forceps application, if necessary, may be undertaken with less danger to mother and child.

Since 1957 the use of forceps has diminished progressively, while that of the vacuum extractor has increased (Table I). We have found that in certain cases the vacuum extractor will not provide the tractive force necessary to overcome a moderate degree of disproportion and will become detached. In certain of these cases delivery by forceps is still possible, but in many the disproportion is such that caesarean section is indicated. We have also felt it desirable to retain forceps for the training

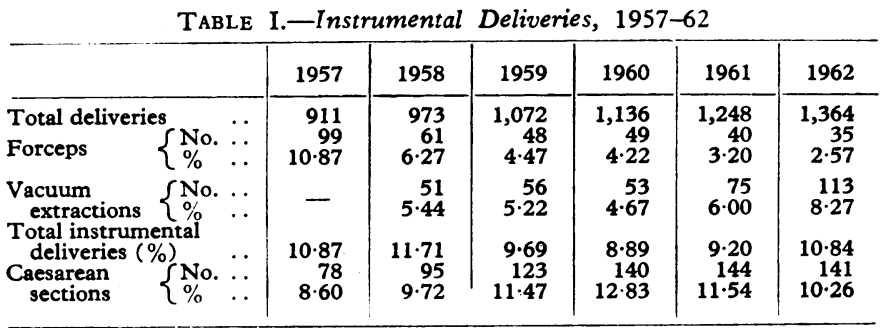

of our house-surgeons in the use of this instrument, still the commonest means of achieving assisted delivery in this country. Were it not for this, the incidence of forceps delivery would have fallen even lower, although, unlike Snoeck (1960) and Malmström (1961), we do not feel that it is possible entirely to eliminate the use of forceps. As our experience of the vacuum extractor has grown we have reduced the percentage of caesarean sections. The figure in this unit is artificially high because we accept all caesarean sections from two other units, one undertaking about 500 deliveries and the other approximately 250 per annum. The perinatal death rate has also fallen over the years (Table II), and we believe that this has been due in part to the use of the vacuum extractor.

\begin{tabular}{|c|c|c|c|c|c|c|}
\hline i & 1957 & 1958 & 1959 & 1960 & 1961 & 1962 \\
\hline Stillbirths $\quad\left\{\begin{array}{l}\text { No. } \\
\% \\
\%\end{array}\right.$. & $\begin{array}{l}36 \\
3.95\end{array}$ & $\begin{array}{c}24 \\
2 \cdot 47\end{array}$ & $\begin{array}{c}48 \\
4 \cdot 48\end{array}$ & $\begin{array}{c}33 \\
2 \cdot 90\end{array}$ & $\begin{array}{c}34 \\
2 \cdot 72\end{array}$ & $\begin{array}{c}37 \\
2 \cdot 71\end{array}$ \\
\hline $\begin{array}{l}\text { Neonatal } \\
\text { deaths }\end{array} \quad\left\{\begin{array}{l}\text { No. } \ldots \\
\%\end{array}\right.$ & $\begin{array}{l}29 \\
3 \cdot 17\end{array}$ & $\begin{array}{c}22 \\
2 \cdot 26\end{array}$ & $\begin{array}{c}25 \\
2 \cdot 33\end{array}$ & $\begin{array}{l}27 \\
2 \cdot 36\end{array}$ & $\begin{array}{c}29 \\
2 \cdot 32\end{array}$ & $\begin{array}{c}26 \\
1.90\end{array}$ \\
\hline $\begin{array}{ccc}\text { Total perinatal } & \text { mor- } \\
\text { tality }(\%) & \ldots & . .\end{array}$ & $7 \cdot 12$ & $4 \cdot 73$ & $6 \cdot 81$ & $5 \cdot 26$ & $5 \cdot 04$ & $4 \cdot 61$ \\
\hline
\end{tabular}

\section{Indications}

Table III gives the indications for which the instrument has been used in each group of 100 cases, numbered I to IV successively. One major advantage which this instrument offers over any other means of assisting vaginal delivery is that it enables us to intervene on account of either foetal or maternal distress before full dilatation of the cervix. As our experience has grown we have intervened more and more often in the first stage of labour. The principal indication has been uterine inertia causing prolongation of the second stage, and a similar prolongation is the commonest reason for intervention in the first stage. In another very large group foetal distress has been the leading indication. It is interesting to observe that with increasing experience we have been intervening in the first stage more and more before foetal distress has been evident. We believe this to be an advantage in that signs of foetal distress may sometimes be followed rapidly by intrauterine death, and that if conditions for the child are unfavourable the sooner it is removed from these conditions the better foetal salvage we are likely to achieve. A variety of maternal conditions, including cardiac and respiratory deficiency, pregnancy toxaemia, and previous uterine scars, have provided a further group of less frequent indications (Table IV). This method of assisting delivery has been found invaluable in recent laparotomy, cough fracture of a rib, myasthenia gravis, and previous subarachnoid haemorrhage.

TABLE III.-Indications for Vacuum Extraction

\begin{tabular}{|c|c|c|c|c|c|c|c|}
\hline \multicolumn{4}{|c|}{ Group } & \multicolumn{2}{|c|}{ First Stage } & \multicolumn{2}{|c|}{ Second Stage } \\
\hline I & $\begin{array}{l}\text { Inertia } \\
\text { Foetal distress } \\
\text { Other }\end{array}$ & $\begin{array}{l}\cdots \\
\cdots\end{array}$ & $\begin{array}{l}\ldots \\
\cdots \\
\cdots\end{array}$ & $\begin{array}{l}9 \\
6 \\
1\end{array}$ & 16 & $\begin{array}{l}52 \\
17 \\
15\end{array}$ & 84 \\
\hline II & $\begin{array}{l}\text { Inertia } \quad \ldots \\
\text { Foetal distress } \\
\text { Other } \quad . .\end{array}$ & $\begin{array}{l}\cdots \\
\cdots \\
\cdots\end{array}$ & $\begin{array}{l}\cdots \\
\cdots \\
\cdots\end{array}$ & $\begin{array}{r}5 \\
21 \\
7\end{array}$ & 33 & $\begin{array}{r}45 \\
20 \\
2\end{array}$ & 67 \\
\hline III & $\begin{array}{l}\text { Inertia } \\
\text { Foetal distress } \\
\text { Other }\end{array}$ & $\begin{array}{l}\cdots \\
\cdots \\
\cdots\end{array}$ & $\begin{array}{l}\cdots \\
\cdots \\
\cdots\end{array}$ & $\begin{array}{r}10 \\
4 \\
5\end{array}$ & 19. & $\begin{array}{l}51 \\
20 \\
10\end{array}$ & 81 \\
\hline IV & $\begin{array}{ll}\text { Inertia } & \cdots \\
\text { Foetal distress } \\
\text { Other }\end{array}$ & $\begin{array}{l}\cdots \\
\cdots \\
\cdots\end{array}$ & $\begin{array}{l}\ddot{y} \\
\cdots \\
\cdots\end{array}$ & $\begin{array}{r}23 \\
12 \\
4\end{array}$ & 39 & $\begin{array}{r}41 \\
15 \\
5\end{array}$ & 61 \\
\hline & Total .. & $\ldots$ & $\ldots$ & & 107 & & 293 \\
\hline
\end{tabular}

TABLE IV.- "Other" Indications (All Groups)

\begin{tabular}{|c|c|c|c|c|c|c|}
\hline rst Stage & & & Second Stage & & & \\
\hline Uterine scar & & & Toxaemia & & & \\
\hline primigravida & $\cdots$ & $\ldots$ & Cardiac insufficiency & & .. & 5 \\
\hline Placenta praevia ... & . & .. & Respiratory insufficiency & . & .. & 1 \\
\hline $\begin{array}{l}\text { Accidental haemorrhage } \\
\text { Toxaemia .. }\end{array}$ & & $\cdots$ & Recent laparotomy & & .. & 2 \\
\hline $\begin{array}{l}\text { Toxaemia } \\
\text { Maternal distress }\end{array}$ & $\cdots$ & $\cdots$ & Previous caesarean section & & $\cdots$ & 1 \\
\hline $\begin{array}{l}\text { Maternal distress } \\
\text { Disproportion }\end{array}$ & $\ddot{0}$ & $\because$ & Disproportion & & $\ddot{0}$ & 1 \\
\hline Cough fracture rib & $\because$ & $\therefore$ & Accidental haemorrhage & $\because$ & $\because$ & \\
\hline Compound presentation & & $\ldots$ & Eclampsia ... & & .. & \\
\hline Hydrocephaly & $\cdots$ & $\cdots$ & $\begin{array}{l}\text { Myasthenia gravis . } \\
\text { Previous subarachnoid hae }\end{array}$ & emor & hage & 1 \\
\hline & & & Cord prolapse & & .. & \\
\hline & & & Elderly primigravida & . & & \\
\hline & & 1 & & & & \\
\hline
\end{tabular}

We have applied the vacuum extractor to five brow presentations, and in three of these, by placing the cup progressively further and further back on the head, we were able to promote flexion and delivery in each case as a vertex presentation, although in one case forceps had to be applied to complete delivery. In a fourth case a small head was delivered as a brow through a large pelvis and in the fifth partial flexion only was achieved, but delivery in this deflexed position required only 10 minutes' traction.

In four cases of breech presentation where the presenting part was arrested high in the pelvis, application of the cup to the anterior buttock enabled us to bring the breech down to a position where further manipulation was facilitated and successful breech extraction completed in all cases. More recently we have tended to undertake caesarean sections in such cases where labour is arrested, and during the past two years no breech presentation has been treated by vacuum extraction.

In 12 cases of twins the vacuum extractor has been used for the delivery of both twins in five cases ; in three the first twin was delivered by this method and in four the second. The instrument is of particular value in delivering second twins, in that it can be safely applied to the second twin even when the head remains high above the brim, and so in many instances enables delivery to be completed much earlier than would otherwise be possible (W. C. W. Nixon, personal communication, 
1962). It can also be employed in cases where the cervix has closed down after delivery of the first child.

\section{Technique}

The larger the cup used the greater the adhesion which can be obtained, and in general we have used the largest cup possible, having regard to the degree of dilatation of the cervix. Although we have used the smallest cup where the cervix is only two fingerbreadths dilated, we believe that, where delivery is required at this stage, caesarean section is generally preferable and we prefer to use the extractor with the cervix half or more dilated. The cup is applied as near to the vertex as possible in order to promote the most favourable attitude of the head. With the right hand traction is applied in the direction of the pelvic axis synchronously with pains. Two fingers of the left hand can ensure that neither cervical tissue nor a vaginal fold is interposed between the scalp and the cup and can also help to promote flexion and rotation of the head if required. If there are no pains, traction will usually promote improved uterine activity and establish contractions. If the head is at a high level in the pelvis, traction in the proper axis, which will automatically be perpendicular to the cup, will necessitate episiotomy, which should be carried out at an early stage. Traction which is not perpendicular to the cup will promote detachment and should be avoided.

A vacuum of minus $0.6-0.8 \mathrm{~kg}$. $/ \mathrm{sq}$. cm. is built up in stages over a period of five to six minutes in order to achieve proper formation of the "chignon," the artificial caput on which satisfactory adhesion depends. As the presenting part descends, improved flexion of the head will help to promote rotation in cases where this is required, and the axis of traction will gradually move forward in conformity with the change of direction of the curve of the birth canal, so that eventual delivery of the head will require traction in an upward direction. At all times, however, this should remain perpendicular to the cup. As soon as the head is delivered, release of the vacuum will be followed by automatic detachment of the cup, and the remainder of the delivery should be completed in the usual way.

\section{Results}

In our first 100 cases 88 were delivered with the vacuum extractor ; in the second, 87 ; in the third, 92 ; and in the fourth, 91. These results might have been improved had the same operator worked throughout, but, as explained above, many of these cases were treated by operators new to the instrument.

In the first 100 cases all the 12 "failures" were delivered with forceps (Table V), but in four treated in the first stage

\begin{tabular}{|c|c|c|}
\hline Group & Total No. & \\
\hline I & 12 & $\begin{array}{l}4 \text { first stage; occiput posterior in } 6 \text {, lateral in } 4 \text {. All } \\
\text { delivered with forceps, after rotation with vacuum } \\
\text { extractor in } 8\end{array}$ \\
\hline II & 13 & $\begin{array}{l}10 \text { first stage; occiput posterior in } 7 \text {, lateral in } 5 \text {. Lower } \\
\text { segment caesarean section in } 3 ; 9 \text { delivered with forceps } \\
\text { after rotation with vacuum extractor in } 4 \text {. } 1 \text { spontaneous } \\
\text { delivery after completion of dilatation of cervix }\end{array}$ \\
\hline III & 8 & $\begin{array}{l}5 \text { first stage ; occiput posterior in } 5 \text {, lateral in } 1 \text {. Lower } \\
\text { segment caesarean section in } 3 \text {; forceps delivery in } 5 \text {, } \\
\text { after rotation with vacuum extractor in } 3\end{array}$ \\
\hline IV & 9 & $\begin{array}{l}7 \text { first stage ; occiput posterior in } 4 \text {, lateral in } 3 \text {. Lower } \\
\text { segment caesarean section in } 3 \text {; forceps delivery in } 6 \text {, } \\
\text { after rotation with vacuum extractor in } 3\end{array}$ \\
\hline
\end{tabular}

cervical dilatation and rotation was completed with the aid of the instrument before forceps were applied, and in some of the other cases foetal distress was regarded as an indication to abandon the attempt and have recourse to forceps. To-day we believe that the gentler action of the vacuum extractor, causing less compression of the head than the forceps, indicates its use in foetal distress, and more than compensates for a somewhat slower delivery.

In the second 100 cases nine were delivered by forceps and three with marked disproportion by caesarean section. The last case was delivered spontaneously after dilatation of the cervix had been completed with the aid of the vacuum extractor.

In the third group there were three cases of caesarean section and five of forceps, in three of which the vacuum extractor had helped to bring the presenting part to a lower level in the pelvis and so to render a forceps delivery safer and easier.

Nine "failures" occurred in the fourth 100 cases, of which seven were deliveries attempted in the first stage, the occiput being posterior in four and lateral in three. Again, three cases required caesarean section; the remainder were delivered with forceps after cervical dilatation in four and rotation with the vacuum extractor in three.

It is obvious that "failure" was commonest, as was to be expected, in the more difficult cases with malrotation of the head and in complete dilatation of the cervix. None the less, in the overwhelming majority of cases even these complications were successfully overcome with the vacuum extractor alone. In nine cases delivered by caesarean section (Table V) the vacuum extractor was used as a trial tractor. In many such cases the trial proved successful and delivery was completed by means of the instrument.

A further great advantage which is claimed for the vacuum extractor is that it makes possible the management of malrotation of the head where the occiput is either posterior or lateral without upward displacement of the head or general anaesthesia, and that it will promote " autorotation" (Evelbauer, 1958) in a more nearly physiological manner than can be achieved in any other way. Our experience shows that the incidence of intervention with the occiput posterior was more or less uniform throughout the series, but that the proportion of successful deliveries increased to $85.1 \%$ in the last 100 cases (Table VI). It will be seen that rotation of the occiput to the front occurred in over two-thirds of these cases, but that in a considerable group the occiput rotated into the hollow of the sacrum and delivery was effected face-to-pubis. We believe that the particular topography of the pelvis and the head concerned are responsible for this particular rotation, which is usually the most favourable position in the circumstances. Even with the occiput lateral, rotation to occipito-posterior occurred in two cases (Table VII). In a few cases rotation has been assisted digitally, but in most it has been spontaneous in res-

TABLE VI.-Malrotation-Occipito-posterior

\begin{tabular}{|c|c|c|c|c|c|c|c|c|c|c|c|c|c|}
\hline \multirow[t]{2}{*}{ Group } & \multirow[t]{2}{*}{ Total } & \multicolumn{2}{|c|}{$\begin{array}{c}\text { Auto- } \\
\text { rotation } \\
\text { to } \\
\text { Occipito- } \\
\text { Anterior }\end{array}$} & \multicolumn{2}{|c|}{$\begin{array}{l}\text { V.E. } \\
\text { Face-to- } \\
\text { Pubis }\end{array}$} & \multicolumn{2}{|c|}{$\mid \begin{array}{c}\text { Spon- } \\
\text { taneous } \\
\text { after } \\
\text { Cervical } \\
\text { Dilatation }\end{array}$} & \multicolumn{2}{|c|}{$\begin{array}{c}\text { Forceps } \\
\text { Rotation } \\
\text { and } \\
\text { Delivery }\end{array}$} & \multicolumn{2}{|c|}{$\begin{array}{l}\text { V.E. } \\
\text { Rotation } \\
\text { and } \\
\text { Forceps }\end{array}$} & \multicolumn{2}{|c|}{$\begin{array}{c}\text { Lower } \\
\text { Segment } \\
\text { Caesarea } \\
\text { Section }\end{array}$} \\
\hline & & No. & $\%$ & No. & $\%$ & No. & $\%$ & No. & $\%$ & No. & $\%$ & No. & $\%$ \\
\hline I & 23 & 7 & $\begin{array}{r}30.4 \\
73.0\end{array}$ & 10 & 43.5 & - & & 2 & $8 \cdot 7$ & 4 & $17 \cdot 4$ & - & \\
\hline II & 29 & 15 & $\begin{array}{r}51.7 \\
65.5\end{array}$ & 4 & 13.8 & 1 & $3 \cdot 4$ & 2 & 6.9 & 5 & $17 \cdot 2$ & 2 & 6.9 \\
\hline III & 26 & 11 & $\begin{array}{r}42.3 \\
76.9\end{array}$ & 9 & $34 \cdot 6$ & - & & 2 & $7 \cdot 7$ & 3 & 11.5 & 1 & $3 \cdot 8$ \\
\hline IV & 27 & 17 & $\begin{array}{r}62.9 \\
85\end{array}$ & 6 & $22 \cdot 2$ & 一 & & 2 & $7 \cdot 4$ & 2 & $7 \cdot 4$ & - & \\
\hline
\end{tabular}

\begin{tabular}{|c|c|c|c|c|c|c|c|c|c|c|c|c|c|}
\hline \multirow[t]{2}{*}{ Group } & \multirow[t]{2}{*}{ Total } & \multicolumn{2}{|c|}{$\begin{array}{c}\text { Auto- } \\
\text { rotation } \\
\text { to } \\
\text { Occipito- } \\
\text { Anterior } \\
\end{array}$} & \multicolumn{2}{|c|}{$\begin{array}{c}\text { Auto- } \\
\text { rotation } \\
\text { to } \\
\text { Occipito- } \\
\text { Posterior } \\
\end{array}$} & \multicolumn{2}{|c|}{$\begin{array}{c}\text { Occipito- } \\
\text { Lateral }\end{array}$} & \multicolumn{2}{|c|}{$\begin{array}{c}\text { Forceps } \\
\text { Rotation } \\
\text { and } \\
\text { Delivery }\end{array}$} & \multicolumn{2}{|c|}{$\begin{array}{l}\text { V.E. } \\
\text { Rotation } \\
\text { and } \\
\text { Forceps }\end{array}$} & \multicolumn{2}{|c|}{$\begin{array}{c}\text { Lower } \\
\text { Segment } \\
\text { Caesarean } \\
\text { Section }\end{array}$} \\
\hline & & No. & $\%$ & No. & $\%$ & No. & $\%$ & No. & $\%$ & No. & $\%$ & No. & $\%$ \\
\hline I & 30 & 24 & 80.0 & $\mid \frac{1}{83}$ & & 1 & $3 \cdot 3$ & 1 & $3 \cdot 3$ & 4 & 13.3 & - & \\
\hline II & 21 & 141 & $\begin{array}{r}|66 \cdot 6| \\
76.1\end{array}$ & & $9 \cdot 5$ & -1 & & 3 & $13 \cdot 4$ & 2 & $9 \cdot 5$ & - & \\
\hline III & $\begin{array}{l}16 \\
25\end{array}$ & $\begin{array}{l}15 \\
22\end{array}$ & $\left|\begin{array}{l}93.6 \\
88.0\end{array}\right|$ & 二 & & $=$ & & $=$ & & $\overline{1}$ & & $\begin{array}{l}1 \\
2\end{array}$ & $\begin{array}{l}6 \cdot 3 \\
8 \cdot 0\end{array}$ \\
\hline
\end{tabular}


ponse to the improvement in the position of the head. Rotation has usually occurred when the presenting part has reached the pelvic floor, but in some instances a late rotation at the outlet has been observed.

\section{Morbidity and Mortality}

Most authorities have claimed that the vacuum extractor offers greater safety for both mother and child, and our experience confirms this. There has been no maternal death in our series. Episiotomy has been necessary in about two-thirds of our cases (Table VIII) and in two of these extension occurred, to involve the anal sphincter. In one, the perineum was extremely oedematous in association with severe toxaemia, and in the other tearing was caused by the shoulders of a very large child after removal of the vacuum cup, with an extremely

TABLE VIII.-Maternal Trauma

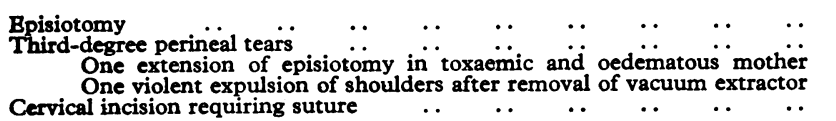

excited and uncontrolled mother. In one case, Duhrssen's incisions were used and the cervix required suture. Apart from this, there was no serious laceration, and at post-natal examination cervical trauma, even in those cases where intervention had been undertaken in the first stage, was found to be no greater than in those cases delivered spontaneously.

With regard to the babies, the total perinatal mortality amounted to 10 cases-of these, seven occurred in the first 100 , or very early in the second 100 . As will be seen from Table IX, two were dead in utero for five hours and five days respectively -one weighed only $1 \mathrm{lb}$. $3 \mathrm{oz}$. (540 g.) and one died during exchange transfusion for severe haemolytic disease. In only two cases was intracranial trauma found at post-mortem examination and one of these was delivered with forceps after failure of vacuum extraction. Apart from these, all the babies left

\section{TABLE IX.-Perinatal Mortality} Stillbirths

\author{
Group I $\ldots\left\{\begin{array}{l}\text { (1) Dead in utero } 5 \text { days } \\ \text { (2) Dead in utero } 5 \text { hour }\end{array}\right.$ \\ Group I $\cdots\left\{\begin{array}{l}\text { (2) Dead in utero } 5 \text { hours } \\ \text { (3) Tentorial tear (forceps delivery) }\end{array}\right.$ \\ Group II .. (4) Delayed second twin'(1 lb. 3 oz. ; 540 g.) \\ Group IV $\{$ (6) Shoulder dystocia in toxaemic diabetic, 40-year-old primipara. \\ $\left\{\begin{array}{l}\text { No antenatal care } \\ \text { (7) Accidental haemorrhage. } 4 \text { lb. }(1,815 \text { g. }) \text { baby }\end{array}\right.$
}

$$
\text { Neonatal Deaths }
$$

Group I .. (8) Intracranial haemorrhage (premature 4 lb. 8 oz.; 2,040 g.) Group II .. $\left\{\begin{array}{l}\text { (9) Foetal distress-placental insufficiency with prolonged anoxia } \\ \text { (10) Severe haemolytic disease (rhesus sensitization) (cord-blood }\end{array}\right.$ At necropsy no intracranial lesion found in Cases $1,2,4,5,6,7,9$, and 10 .

hospital in good condition and subsequent progress has been satisfactory. Fifteen had evidence of cerebral irritation after difficult labours (Table X), but these were mild cases and settled down rapidly. The chignon, the artificial caput, which is essential to the method, is a formidable swelling on removal of the cup, but within a few minutes it is indistinguishable from the normal caput succedaneum. Bruising of the area may per-

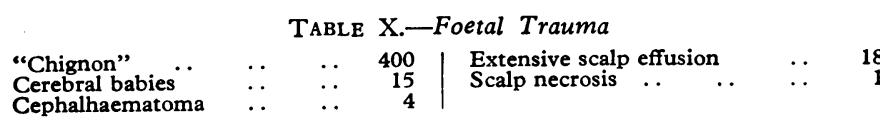

sist for a few days, but in all cases it cleared up by the time the child left hospital on the eighth to tenth day, and the same was true of the peripheral scalp abrasion which was observed in half of the more difficult cases. Scalp necrosis occurred in only one case, in which the cup was applied for two periods of 40 minutes. This was represented by a small crescentic area, which was completely healed within three months, leaving a small linear scar which is no longer apparent since the baby's hair has grown. Cephalhaematoma occurred in only four cases in the whole series, although some widespread scalp oedema was seen in 18 cases. All these ran a rapid course towards cure and caused no anxiety.

\section{Discussion}

The results of five years' experience of the use of the Malmström vacuum extractor have convinced us at Worcester of the value of the method, and of its safety for mother and child. From time to time accounts have been published of mishaps to the mother, but it is questionable whether indeed these have been attributable to the instrument, and in the context of the vast number of vacuum extractor deliveries performed throughout the world the numbers have been remarkably few.

A note of warning has been sounded by Huntingford (1961) with regard to injury to the foetus, but his paper selectively describes 11 particularly unfavourable cases, and, even in these, all but two infants were rescued from their unhappy predicament, although two required forceps delivery and one caesarean section. One of the deaths was due to atelectasis, in the child delivered by caesarean section; but in the second, delivery with the vacuum extractor, intracranial haemorrhage occurred from a tear in the falx cerebri. All the other babies eventually made satisfactory progress, although four showed signs of cerebral irritation.

From Singapore, Wong (1961) described a high incidence of foetal trauma, with cephalhaematoma in $30 \%$, scalp necrosis in six $(11.6 \%)$ of 52 cases, and neurological involvement in $9.3 \%$ of his cases. Even in this series, however, there were only three deaths in 160 cases. Although scalp abrasion has often been seen in our cases, infection has never occurred and all have healed rapidly. Our experience with regard to both morbidity and mortality in our large series has given us no cause for dissatisfaction with the method. We have been impressed with the ease and rapidity with which delivery has often been completed in the most unpromising circumstances. In many cases no more than a single pain has been required to effect delivery, and it is rarely that longer than 15 minutes elapses between the first application of the cup and delivery. We no longer continue traction for more than 30 to 40 minutes. Our one case of scalp necrosis was the only one in which application of the vacuum extractor exceeded one hour, and we have never favoured the method of continuous traction by weights over many hours as described by Alment (1960). Careful assessment of the position of the head and its level in the pelvis, and accurate placing of the cup as near the vertex as possible (with reapplication if necessary), should ensure a near-physiological mechanism of delivery and minimize trauma. If disproportion of more than moderate degree is present, this is usually soon evident and no advance will occur, or the cup will become detached. In such cases an alternative method of delivery should be sought.

The uncorrected perinatal mortality (Table IX) in our series amounted to 10 cases $(2.5 \%)$, but the great majority of the deaths were unrelated to the method of delivery, and intracranial injury was demonstrated at necropsy in only two casesone delivered with forceps and one a premature baby weighing only $4 \frac{1}{2} \mathrm{lb}$. $(2,040 \mathrm{~g}$.). In general, we believe that the progressive reduction in perinatal mortality shown in Table II is due, at least in part, to our ability to rescue the infant from an unfavourable environment by vacuum extraction earlier than would be possible by any other method (de Azevedo, 1959).

The use of the vacuum extractor in domiciliary practice has been discussed in an earlier paper (Fothergill and Chalmers, 1961). Here the opinion was expressed that the occasional operator would find the instrument a safer alternative to forceps in the type of case regarded as suitable for operative delivery at home-namely, where the presenting vertex is below the level of the ischial spines and the occiput within about 45 degrees of the 
anterior position. The more experienced practitioner may wish to extend the range of his intervention, but this should be limited to institutional conditions. There are many general practitioners in this country, including several of our former house-surgeons, who are using the instrument successfully. Further extension of this trend would help to reduce the dangers of forceps in unpractised hands and lead to improved figures for infant survival in the home, as we believe it has in the hospital.

\section{Summary}

The Malmström vacuum extractor has been employed for 400 deliveries at the Obstetric Unit, Ronkswood Hospital, Worcester, during 1948-63. In this time the incidence of vacuum extraction has increased progressively, while that of forceps delivery has fallen.

Foetal mortality has fallen progressively, and recently there has been a fall in the incidence of caesarean section. It is suggested that both of these are due in part to the use of the vacuum extractor.

Indications are described for the use of the instrument in both the first and the second stage of labour, and the results are detailed.
The method has proved effective in cases of malrotation of the foetal head and of foetal distress, and results for both mother and foetus have been satisfactory.

I am grateful to my colleague Mr. A. T. Marshall for permission to quote many of his cases included in the above series.

\section{REFERENCES}

Alment, E. A. J. (1960). Proc. roy. Soc. Med., 53, 759.

Chertkoff (1961). Proceedings of Third International Congress of Obstetrics and Gynaecology, Vienna, 1, 380.

de Azevedo, G. (1959). Portugal méd., 43, 75.

Dragotescu, C. C., and Roman, I. (1962). Vidextractia Obstetricala, Bucharest.

Evelbauer, K. (1958). Fortschr. Med., 76, 553.

(1961). Proceedings of Third International Congress of Obstetrics and Gynaecology, Vienna, 1, 82

Fothergill, R. J., and Chalmers, J. A. (1961). Practitioner, 186, 559.

Huntingford, P. J. (1961). Lancet, 2, 1054.

Malmström, T. (1961). Proceedings of Third International Congress of Obstetrics and Gynaecology, Vienna, 1, 47.

Rüther, E., and Sokol, K. (1961). Geburtsh. u. Frauenheilk., 21, 245.

Snoeck, J. (1960). Proc. roy. Soc. Med., 53, 749.

Wong, H. B. (1961). F. Singapore paediat. Soc., 3, 56.

Yonge, J. (1706-7). Phil. Trans. B, 25-26, 2387.

\title{
Serum Transaminase Activity in Status Asthmaticus
}

\author{
A. H. EL-SHABOURY,* M.B., D.C.H. ; A. J. THOMAS,* M.D., F.R.C.P. \\ D. A. WILLIAMS,* M.D., M.SC., F.R.C.P.
}

Brit. med. F., 1964, 1, 1220-1223

It has been established by Karmen (1955) that serum glutamic oxaloacetic transaminase (S.G.O.T.) activity was increased after cardiac infarction. The S.G.O.T. is of especial value when the electrocardiograph shows bundle-branch block, left ventricular strain, or previous myocardial infarction, or when digitalis obscures the changes (Dewar et al., 1958). In experimental tissue injury a rough correlation has been found between the amount of tissue injury and the peak level of S.G.O.T. (Rudolph et al., 1957), and cases of cardiac infarction with values over 200 or 250 units $/ \mathrm{ml}$. have been shown to carry a poor prognosis (Chinsky et al., 1956 ; Bruce et al., 1958). In small infarctions serial estimations may show a diagnostic curve even though the peak level does not exceed 40 units $/ \mathrm{ml}$., the upper limit of normal (Baron et al., 1958 ; Dewar et al., 1958).

It is also widely accepted that raised levels of S.G.O.T. and serum glutamic pyruvic transaminase (S.G.P.T.) occur in acute liver damage (Wroblewski and La Due, 1955, 1956a, 1956b ; Chinsky et al., 1957 ; Madsen et al., 1958). Increases may occur in patients receiving morphine, salicylates, chlorpromazine, and ethyl alcohol ; in skeletal disorders and acute pancreatitis (Wroblewski, 1959); and in atopic eczema and other skin diseases (Tickner et al., 1961). It appears unlikely that steroids have any influence on S.G.O.T. activity (Vickers, 1961).

Elevated S.G.O.T. activity was found in cardiac failure without evidence of cardiac infarction (Fragge et al., 1960). The highest levels (555 units $/ \mathrm{ml}$.) were found in patients with chronic lung disease and right heart failure. The rapidity of onset of failure in influencing the enzyme levels was emphasized.

- St. David's Hospital, Cardiff.
In 224 patients with acute cardiac failure West et al. (1961) also found elevation of S.G.O.T. and S.G.P.T. in the absence of cardiac infarction. They refer to elevation of glycolytic enzymes (lactic dehydrogenase, aldolase, and phosphohexose isomerase), possibly due to anoxia, in more than half of the patients with severe acute episodes of bronchial asthma.

Colldahl $(1960,1961)$ studied the serum enzymes in patients with "asthma and emphysema" and found definitely raised levels in about $25 \%$ of 125 asthmatic patients with varying degrees of dyspnoea. The S.G.P.T. especially was increased, the aldolase and ornithine carbamyl transferase (O.C.T.) were also sometimes elevated. Raised S.G.O.T. activity occurred in two cases with severe asthma in the absence of cardiac infarction as proved at necropsy.

Our interest arose when a patient aged 60 (Case 1 ; see Table), admitted in status asthmaticus, complained of "tightness" of his chest 36 hours after admission, while still severely distressed from his asthma. Serum enzyme estimations carried out on three successive days were S.G.O.T. 202, 147, and 116 units $/ \mathrm{ml}$. and S.G.P.T. 43, 47, and 52 units/ml. respectively. The electrocardiogram remained normal throughout his six weeks' stay in hospital and has remained so since. The high S.G.O.T. levels made us initially consider this case as one of possible cardiac infarction complicating status asthmaticus. Our subsequent experience makes this diagnosis unlikely. Recently a woman aged 30 was admitted in status asthmaticus to another hospital under the care of one of us (D.A.W.) and died within three days. The S.G.O.T. was 53 units $/ \mathrm{ml}$. on the second day. At necropsy the coronary arteries and myocardium were healthy, while the liver showed chronic venous congestion. 